\title{
Software Freight Forwarding Angkutan Darat untuk Antar Propinsi Menggunakan SDLC Water Fall
}

\author{
Devi Yurisca Bernanda ${ }^{1}$, Ozmar Azahari ${ }^{2}$ \\ 1,2 Sistem Informasi, Universitas Bunda Mulia \\ JI. Lodan Raya No. 2 Ancol, Jakarta Utara 14430, Indonesia \\ e-mail: 1dbernanda@bundamulia.ac.id, ²ozumaru@yahoo.com
}

\begin{tabular}{llll}
\hline Informasi Artikel Diterima: 17-05-2021 Direvisi: 25-06-2021 & Disetujui: 29-06-2021 \\
\hline
\end{tabular}

\begin{abstract}
Abstrak
Penyedia Jasa Logistik atau yang biasa disebut dengan Third Party Logistics (3PL) adalah merupakan pihak yang melayani kebutuhan pengiriman barang. Layanan logistik tersebut paling banyak didominasi oleh jasa pengiriman dan penyimpanan barang melalui angkutan darat. Permasalahan penyebab tingginya biaya pengiriman antar pulau atau propinsi di Indonesia, terutama untuk pengiriman barang adalah kualitas infrastruktur dan fasilitas pelabuhan yang tidak memadai, serta manajemen jasa angkutan darat untuk pengiriman barang yang di miliki oleh pelaku usaha. Kendala yang dihadapi oleh manejemen perusahaan dan pelaku usaha serta pengemudi angkutan barang adalah sulitnya memanajemen armada, biaya dan penjadwalan pengiriman barang dari konsumen atau client secara cepat dan tepat waktu. Pelaku usaha dapat menggunakan Less Container Load (LCL) untuk mengirimkan barang atau komoditi dengan jumlah kurang dari jumlah muatan kontainer, yang artinya barang dari beberapa perusahaan dapat disatukan didalam satu container untuk dikirimkan secara bersamaan untuk menghemat biaya. Penelitian ini dilakukan dengan tahapan studi pustaka, dan wawancara serta observasi lapangan. Studi pustaka dilakukan oleh peneliti untuk menemukan konsep metodologi yang sesuai untuk melakukan pengembangan Software Freight Forwarding Angkutan Darat untuk Pengiriman Barang Antar Propinsi. Metode yang digunakan untuk pengembangan ini adalah menggunakan SDLC Waterfall. Hasil dari penelitian ini adalah perusahaan jasa angkutan ini telah dapat meningkatkan proses bisnis dan pendapatannya secara signifikan serta kinerja operationalnya meningkat dengan lebih baik.
\end{abstract}

Kata Kunci: Software Freight Forwarding; SDLC Water Fall,;Angkutan Darat

\begin{abstract}
Logistics Service Providers or commonly referred to as Third Party Logistics (3PL) are parties that serve the needs of shipping goods. Logistics services are mostly dominated by goods delivery and storage services via land transportation. The problems that cause the high cost of shipping between islands or provinces in Indonesia, especially for the delivery of goods, are the inadequate quality of port infrastructure and facilities, as well as the management of land transportation services for goods delivery owned by business actors. The obstacles faced by company management and business actors as well as freight drivers are the difficulty in managing the fleet, costs and scheduling the delivery of goods from consumers or clients quickly and on time. Business actors can use Less Container Load (LCL) to ship goods or commodities with an amount less than the total container load, which means that goods from several companies can be put together in one container to be shipped simultaneously to save costs. This research was conducted with the stages of literature study, and interviews and field observations. The literature study was carried out by researchers to find a suitable methodological concept for developing Land Transportation Freight Forwarding Software for InterProvincial Freight Forwarding. The method used for this development is using SDLC Waterfall. The result of this research is that this transportation service company has been able to significantly improve its business processes and revenue and improve its operational performance.
\end{abstract}

Keywords: Software Freight Forwarding; SDLC Water Fall; Land Transportation 


\section{Pendahuluan}

Bisnis 3PL teresbut diperkirakan memiliki rata-rata pertumbuhan sekitar 5-10 persen di seluruh dunia sampai tahun 2024 (Majalah Pajak, 2021). Layanan logistik tersebut paling banyak didominasi oleh jasa pengiriman dan penyimpanan barang melalui angkutan darat. Kementerian Perhubungan terus berupaya menjaga angkutan barang logistik berjalan lancar di tengah pandemi Covid-19 yang melanda wilayah di Indonesia (SmartLogistik, 2020). Hal itu untuk menjaga ketersediaan logistik nasional khususnya kebutuhan dasar masyarakat, sehingga perekonomian dan kesejahteraan masyarakat tetap terjaga. Adapun Presiden Joko Widodo menegaskan bahwa masa pandemi jangan sampai menghambat distribusi logistik seperti bahanbahan pokok, barang-barang penting untuk kegiatan ekonomi, obat-obatan, dan alat-alat kesehatan.

Urgensi Penelitian ini adalah meningkatkan daya saing antar perusahaan jasa angkutan darat di bidang pengiriman barang antar propinsi terutama bagi para pelaku usaha yang sering mengirimkan barang dalam jumlah besar dari segi biaya dapat ditekan, penjadwalan mengirim barang dalam jumlah besar ataupun sedikit, serta biaya operasioanl yang dikeluarkan jauh lebih murah dan juga proses perencanaan yang efektif serta membantu kelancaran pekerjaan angkutan barang, terutama untuk pembuatan laporan internal manajemen perusahaan, sehingga mereka dapat meningkatkan proses bisnis dan meningkatkan pendapatan (Gunawan et al., 2021).

Tujuan dari pengembangan software ini yaitu yang dapat meningkatan kinerja operasional Manajemen Perusahaan Angkutan darat untuk pengiriman barang antar propinsi dan dapat memberikan laporan yang baik ke internal manajemen perusahaan berupa laporan Job Sheet Book, Laporan LCL / Shipper, Laporan Rebate Warehouse dan Laporan Listing Approval Job serta laporan antar department di internal perusahaan logistik.

\section{Metode Penelitian}

Penelitian ini melakukan prosedur langkah-langkah yang digambarkan pada diagram alir pada Gambar 1 Metode Penelitian. lain: Metode penelitian yang dilakukan antara

1. Tahap pertama: peneliti melakukan 3 metode pengumpulan data yang digunakan untuk menyelesaikan penelitian ini yaitu wawancara dan observasi lapangan serta studi pustaka (Madyatmadja et al., 2021). a. Metode wawancara: melakukan tanya jawab kepada pengguna salah satu perusahaan yang melakukan bisnis di bidang jasa Angkutan Darat untuk Pengiriman Barang Antar Propinsi.

b. Metode observasi: melakukan pengamatan yang dilakukan dengan mengunjungi perusahaan terkait yang diambil peneliti sebagai objek dan melihat cara kerja langsung bagaimana proses Angkutan Darat untuk Pengiriman Barang Antar Propinsi tersebut.

c. Metode studi pustaka: mengumpulkan data dari berbagai jenis buku, jurnal, artikel dan literatur lainnya yang akan digunakan sebagai landasan teori.

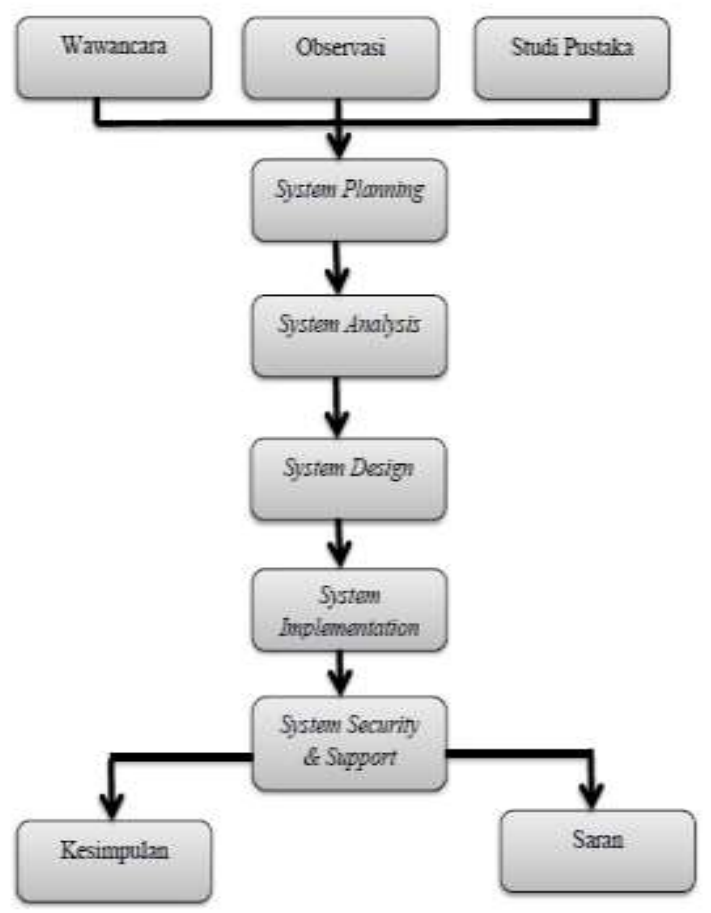

Gambar 1. Metode Penelitian (Andry et al., 2016).

Digunakannya system development life cycle (SDLC) digunakan untuk rancang bangun software dengan dan fase rancang bangun reguler seperti system planning, systems analysis, system design, system implementation dan sytems security and support di akhir proyek (Egwoh \& Nonyelum, 2017). Water Fall merupakan sebuah adalah model pengembangan paling sederhana dari antara daftar rancang bangun perangkat lunak yang tersedia. Semua langkah kerangka SDLC water fall ini dilakukan satu demi satu melalui cara linier (Gharajeh, 2019). Tahapan rancang bangun ini digunakan untuk melakukan kegiatan dalam menyusun sebuah software yang akan dilakukan agar dapat mencapai hasil 
yang diinginkan. Sebab itu, tahapan ini akan sangat bermanfaat bagi yang sedang melakukan pengembangan sistem (Bassil, 2012) \& (Andry \& Honni, 2017). Tahapan SDLC menggunakan water fall, diperlihatkan pada Gambar 2. SDLC Water Fall.

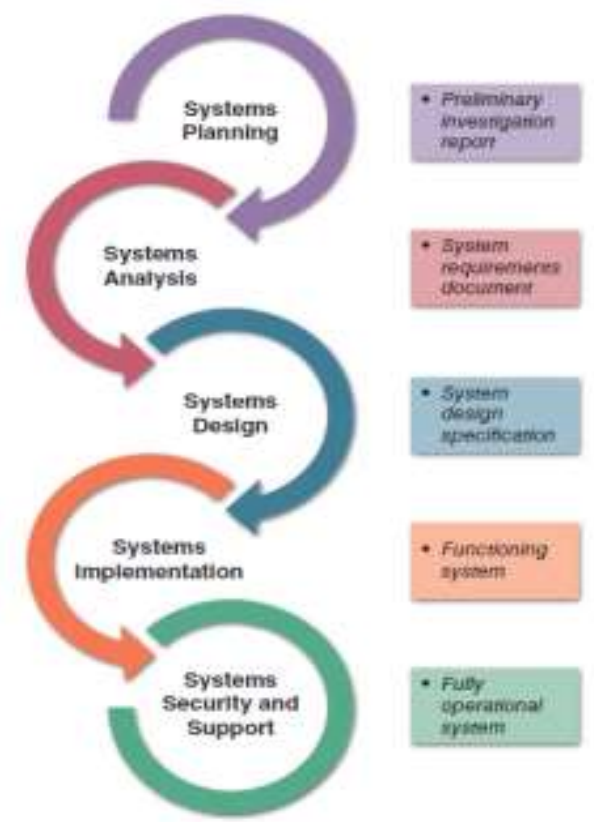

Gambar 2. SDLC Water Fall (Tilley \& Rosenblatt, 2017).

2. Tahap kedua: peneliti mulai melakukan penelitian dengan System Planning, lebih menekankan pada aspek studi kelayakan pengembangan sistem sebagai dasar rancang bangun software ini dan memahami bisnis proses yang berlangsung (Suryantara \& Andry, 2018). Tujuan utama dari tahap ini adalah untuk mengetahui apa itu pengumpulan persyaratan sebenarnya dibutuhkan oleh pengguna dan dokumentasikan dengan tepat. Dalam analisis kebutuhan tahap, yang lebih ditekankan adalah dalam mengidentifikasi apa yang dibutuhkan dari sistem (Sudarsono et al., 2020).

3. Tahap ketiga: peneliti mulai melakukan penelitian dengan System Analysis, mengklasifikasikan masalah, peluang, dan solusi yang mungkin diterapkan untuk kasus tersebut, untuk rancang bangun Software Angkutan Darat untuk Pengiriman Barang Antar Propinsi. Tahapan ini dilakukan kegiatan analisis dimana pengembang akan melakukan wawancara dengan staf dan manajemen serta pelaku usaha yang menangani proses pengiriman barang dan mengumpulkan detail penting serta menanyakan persyaratan dan harapan dari pengguna sistem ini (Amron et al., 2018). Pemodelan sistem yang digunakan yaitu Unified Modelling Language (UML) yang terdiri dari beberapa diagram antara lain Use-Case Diagram dan Activity Diagram. Use case membantu untuk memahami dan mengklarifikasi persyaratan pengguna untuk interaksi dengan sistem dan mengungkapkannya sebagian besar atau semua persyaratan fungsional sistem baru (Andry et al., 2018).

4. Tahap keempat: peneliti mulai melakukan penelitian dengan System Design, pada tahap ini, modul-modul dan operasi-operasi pada sistem dideskripsikan secara detail. Aktivitasaktivitas yang dilakukan adalah menganalisa interaksi obyek dan fungsi pada sistem dan membuat user interface. User interface ini sendiri memiliki desain yang berbeda-beda berdasarkan fungsi dan kebutuhannya (Geasela et al., 2018) \& (Nurlifa et al., 2014).

5. Tahap kelima: peneliti mulai melakukan penelitian dengan System Implementation, pada tahap ini adalah mengimplementasikan rancangan dari tahap-tahap sebelumnya dan melakukan uji coba metode testing dengan menggunakan UAT (user acceptance testing) (Andry et al., 2018).

6. Tahap keenam: peneliti mulai melakukan penelitian dengan System Support \& Security, pada tahap ini adalah menjaga sistem tetap mampu beroperasi secara benar melalui kemampuan sistem dalam mengadaptasikan diri sesuai dengan kebutuhan dan menentukan apakah aplikasi sudah sesuai dengan kebutuhan dari pengguna.

7. Tahap ketujuh: peneliti menutup penelitian ini dengan menarik kesimpulan dan saran dari hasil penelitian ini.

\section{Hasil dan Pembahasan}

\subsection{System Planning (Preliminary Investigation Report)}

Pada system planning ini software atau perangkat lunak yang dibuat berdasarkan requirement Software Freight Forwarding Angkutan Darat untuk Pengiriman Barang Antar Propinsi, yang didapatkan dari wawancara serta observasi di lapangan kepada user atau karyawan perusahaan angkutan darat, dimana di dalamnya menjelaskan mengenai fungsifungsi serta tujuan yang diharapkan bisa dilakukan oleh software dalam memenuhi semua proses pengiriman dan penerimaan barang antar propinsi melalui jasa kargo.

Permintaan (requirement) ini dibangun dengan tujuan untuk membantu kegiatan Software Freight Forwarding Angkutan Darat untuk Pengiriman Barang Antar Propinsi yang akan dilakukan, yaitu:

- Membantu proses kirim dan terima barang antar propinsi

- Membantu dalam proses pemasukan serta pengeluaran barang. 
- Memudahkan perusahaan dalam melakukan pemesanan barang ke luar kota dan antar propinsi

- Memudahkan perusahaan dalam melakukan pengiriman barang ke luar kota dan antar propinsi

- Mempermudah proses pencatatan data perusahaan ketiga yang bekerjasama.

- Mempermudah proses pengecheckan barang menggunakan $\mathrm{B} / \mathrm{L}$ (Bill of Lading).

- Terdapat penyimpan histori mengenai data transaksi yang telah dilakukan.

- Mempermudah pengelolaan data karyawan, perusahaan, dan lokasi.

- Mempermudah pencarian data perusahaan, barang dan container.

- Memberikan pemberitahuan pada saat barang sudah tiba.

Adapun ruang lingkup proses ini diantaranya sebagai berikut:

- Setiap data utama akan disimpan dalam database DBF seperti data karyawan/supervisior, petugas lapangan ,data perusahaan, dan lain-lain.

- Proses kirim dan terima barang antar kota dan propinsi akan menjadi fungsi utama dalam Software Freight Forwarding Angkutan Darat

- Setiap data yang ada dapat dilihat oleh TOP supervisior yang bersangkutan.

- Menyediakan fungsi reporting (pelaporan) mengenai pemasukan dan pengeluaran barang serta invoice dan sales commission.

adalah

Hal utama yang menjadi latar belakang

- Belum terdapat proses pengiriman dan penerimaan barang, monitoring, pencatatan transaksi penerimaan barang kepada pemasok, dan pencatatan data perusahaan,.

- Terdapatnya beberapa kesalahan mengenai pemasukan dan pengeluaran data yang dilakukan.

- Terjadi kesalahan pada proses reporting perusahaan.

- Tidak ada sistem yang terintegrasi untuk proses pemasukan dan pengeluaran serta penerimaan dan pengiriman barang, monitoring, pencatatan transaksi permintaan barang kepada pemasok, pencatatan transaksi penjualan, dan reporting.

Objective yang akan di capai untuk Software Freight Forwarding Angkutan Darat adalah

- Menyediakan sistem yang berbasis desktop untuk memproses pendataan container dan service.

- Menyediakan sistem yang berbasis desktop untuk memproses pendataan tempat penyimpanan barang.

- Menyediakan sistem yang berbasis desktop untuk memproses pendataan pelabuhan.
- Menyediakan sistem yang berbasis desktop untuk memproses pendataan perusahaan pihak ketiga.

- Menyediakan sistem yang berbasis desktop untuk memproses pendataan tujuan pengiriman barang.

- Menyediakan sistem yang berbasis desktop untuk memproses pendataan tempat memuat barang.

- Menyediakan sistem yang berbasis desktop untuk memproses pencatatan transaksi menggunakan B/L Number.

- Menyediakan sistem berbasis dekstop untuk pencatatan daftar harga setiap jasa kirim dan terima barang antar kota dan propinsi

- Menyediakan sistem yang berbasis desktop untuk melakukan monitoring yang dapat dilihat oleh semua pihak yang terkait.

- Menyediakan fasilitas untuk men-generate laporan secara otomatis menggunakan sumber data yang ada di dalam sistem yang tersedia.

- Menyediakan sistem yang dapat membantu pengguna dalam melakukan complain dengan mudah menggunakan pesan yang dikirimkan kepada pihak yang terkait mengenai complain tersebut.

\subsection{System Analysis (System Requirement Documents)}

User yang akan menggunakan aplikasi ini terdari dari owner, supervisior, employee, dan customer.

- Top Supervisor adalah akun yang dapat melakukan semua aktifitas dan dapat mengakses setiap data yang ada serta dapat melihat laporan-laporan yang ada.

- Supervisor adalah akun yang memiliki fungsi mirip seperti owner dimana supervisor dapat melihat aktifitas transaksi, re-stock barang, serta supervisor dapat melakukan pemasukkan data akun supplier.

- Supervisor Hider adalah akun yang dapat melakukan konfirmasi transaksi, pesan re-stock barang serta mengatur complain dari customer. - Marketing adalah akun dapat melakukan akses read-only ke daftar harga semua jasa ekspedisi di dalam perusahaan.

- Read Only adalah akun yang disimpan untuk di-inputkan kedalam proses pemesanan stok barang, dan yang akan menerima print out dari laporan pemesanan stok barang yang ada.

Pada Gambar 4 merupakan use-case Aplikasi Freight Forwading secara umum beserta aktoraktor yang terlibat. Tugas tiap aktor beragam dari Top Supervisor, Supervisor, Supervisor hider, Marketing, Document Department, Account Department, Staff LCL, Staff FCL, Staff Air Freight Import, Staff Air Freight Export, hingga Staff Sea Freight Import. Secara hirarki, semakin tinggi jabatan dalam perusahaan maka 
semakin tinggi tingkat akses aktor di dalam aplikasi. Masing-masing usecase secara general yang mewakili usecase yang lebih spesifik. Detil use case diperlihatkan pada Gambar 3. System Use-Case Aplikasi Freight Forwading Angkutan Darat.

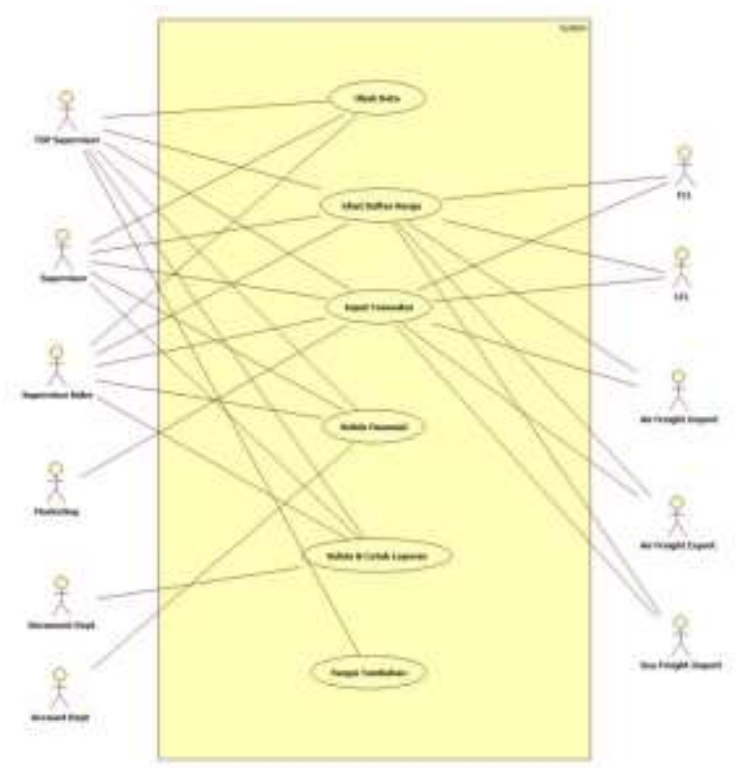

Gambar 3. System Use-Case Aplikasi Freight Forwading Angkutan Darat

\subsection{System Design (system design specification)}

Pada system design yang di usulkan bisa dilihat Pada Gambar 3. System Design yang diusulkan, bisa di jelaskan sebagai berikut:

1.0 Data Utama, terdiri dari:

1.1 type container

1.2 type service

1.3 stuffing location

1.4 port destination,

1.5 port of loading

1.6 trucking company

1.7 shipping company

1.8 agent company

1.9 warehouse

1.10 export/shipper

1.11 notify

1.12 consignee import

1.13 shipper Import

2.0 Pricelist, terdiri dari:

2.1 Export,

2.1.1 selling price export:,
2.1.2 incentive from agent,

2.1.3 rebate from coloader,

2.1.4 heavy weight surcharges,

2.1.5 searching selling rate,

2.2 Cost

2.1.6 Quatation from agent

2.2.1 Feeder Rate,

2.2.2 Price Agent,

2.2.3 Price Trucking,

2.2.4 Warehouse Dan

2.3 Import,

2.2.5 Operational.

2.3.1 Mechanic Charges,

2.3.2 Do Charges (Std),

2.3.3 Do Charges (Special)

3.0 Transaction, terdiri dari:

3.1 Stuffing Plan,

3.2 Job Order,

3.3 Permohonan Pengambilan B/L, 3.4 Arrival Notice.

4.0 Finance, terdiri dari:

4.1 Invoice To Shiiper,

4.2 Crdit Note,

4.3 Credit Note,

4.4 Finance Proses,

4.5 Refund Voucher,

4.6 Bukti Pengeluaran Kas Dan

4.7 Arrival Notice.

5.0 Report, terdiri dari:

5.1 Job Sheet Book,

5.2 Lap. LCL (Shipper),

5.3 Lap. LCL (Sales),

5.4 Recap Job Sheet,

5.5 Reabate Warehouse,

5.6 Listing Approval Jobs,

5.7 Listing Refund Belum Lunas,

5.8 Listing Job Belum Buat Invoice,

5.9 Lap. Per Department,

5.10 Lap. Booking Via Inesia,

5.11 Lap. Profit Via Agent,

5.12 Lap. Sales Commission.

6.0 Utility, terdiri dari:

6.1 Seach File B/L Number,

6.2 Search File From Container Numbers,

6.3 Search File From Container Consignee/Notify,

6.4 Search Invoice Number,

6.5 Agenda Invoice Dan CN,

6.6 Status Data, dan

6.7 Proses Awal Tahun. 


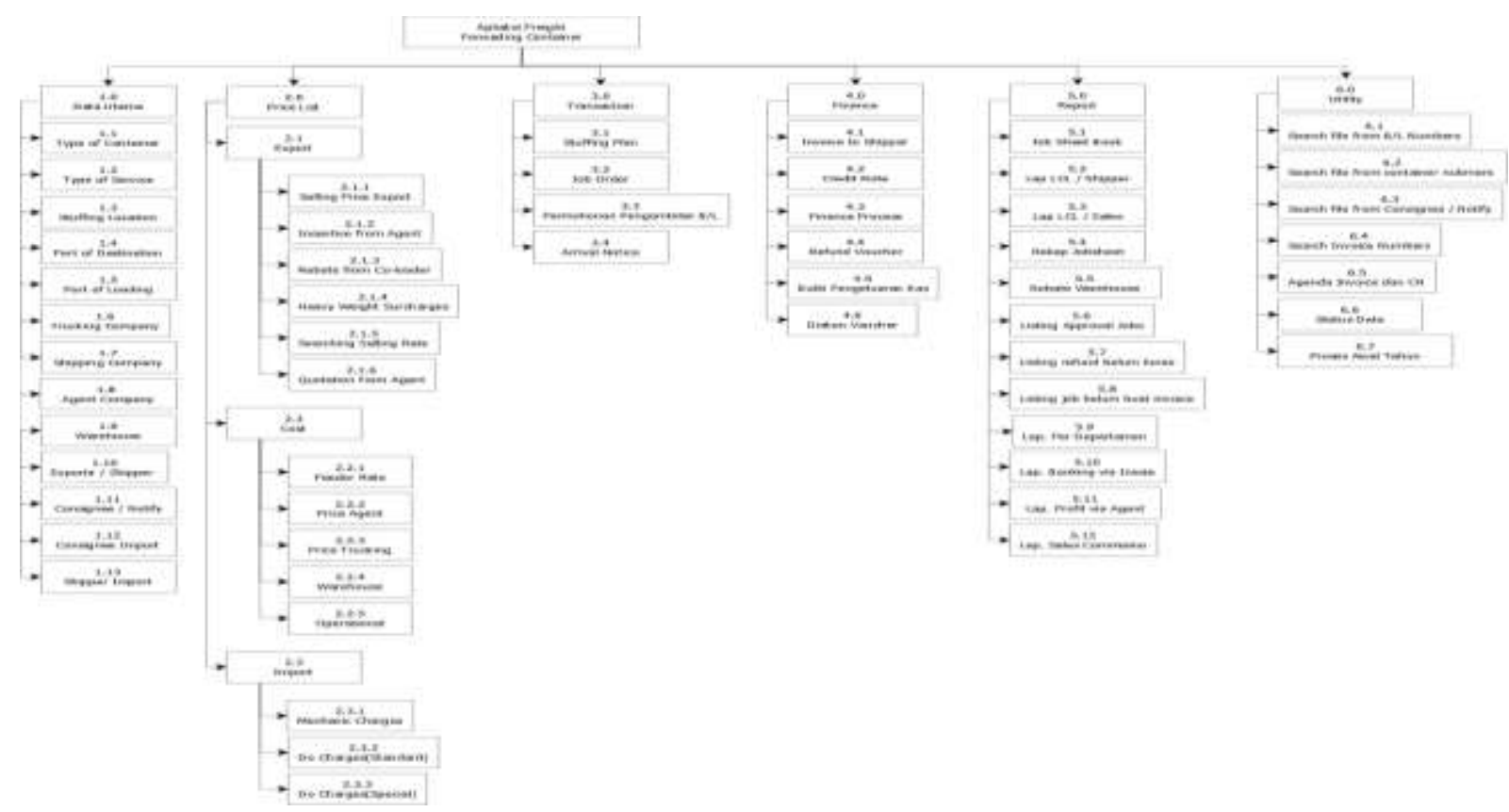

Gambar 4. System Design Yang Diusulkan

\subsection{System Implementation (functioning systems)}

Pada implementasi software ini, atau fungsi pada sistem pada parameter ini mempunyai syarat hanya berlaku untuk setiap job site. Sehingga setiap job site bisa jadi mempunyai nilai parameter yang berbeda. Berikut adalah parameter yang digunakan pada Aplikasi Freight Forwading. Parameter yang digunakan dalam aplikasi ini antarai lain sebagai berikut:

- Tipe User ada user Top Supervisor, Supervisor, Supervisor Hider, Read Only, Marketing Dept, Document Dept, Account Dept, FCL, LCL, Air Freight Export, Sea Freight Export, dan Air Freight Impor.

- Tipe kontainer: 40", 20", Mobil Box

- Tipe layanan terdiri dari Ocean Freight, Document, O/F AGENT, Trucking, W/H, Overnight, Clearance, Mekanik, Do Charges, PPn 10\%, Air Freight, Agency Fee, PNBP, LPBC

- Tipe Lokasi Penempatan Barang, bisa di tempatkan di Jakarta, Semarang, Surabaya, Medan, Palembang, Makasar, Menado, Pontianak, Banjarmasin, Ambon dan Bali.

- Hak akses TOP Supervisor yaitu Dapat melakukan semua aktifitas dan dapat mengakses setiap data yang ada serta bebas melakukan perubahan, pengaturan, dan modifikasi terhadap aplikasi yang ada, Dapat melakukan pemasukkan data employee dan supervisor, Dapat menambahkan pengguna

- Hak akses Supervisor yaitu Dapat mengakses data container, Dapat mengakses data layanan, Dapat mengakses data lokasi penempatan barang, Dapat mengakses data port of destination, Dapat mengakses data port of loading, Dapat mengakses data trucking company, Dapat mengakses data shipping company, Dapat mengakses data agent company, Dapat mengakses data exportir, Dapat mengakses data consignee / notify, Dapat mengakses data consignee import, Dapat mengakses data shipper import, Dapat mengakses data airline, Dapat mengakses data sales, Dapat mengakses data petugas lapangan, Dapat mengakses data harga export, Dapat mengakses data tagihan, Dapat mengakses data harga import, Dapat mengakses data transaksi stuffing plan, Dapat mengakses data transaksi job order, Dapat mengakses data transaks permohonan pengambilan $\mathrm{B} / \mathrm{L}$, Dapat mengakses data transaksi arrival notice, Dapat mengakses data finansial invoice to shipper, Dapat mengakses data finansial credit note, Dapat mengakses data finansial finance process, Dapat mengakses data finansial refund voucher, Dapat mengakses data finansial bukti pengeluaran kas, Dapat mengakses data finansial discount voucher, Dapat mengakses semua laporan, Dapat mengakses fungsi pencarian data pada database yang bisa diakses oleh Supervisor.

- Hak akses Supervisor Hider yaitu Dapat mengakses data container, Dapat mengakses data layanan, Dapat mengakses data lokasi penempatan 
barang, Dapat mengakses data port of destination, Dapat mengakses data port of loading, Dapat mengakses data trucking company, Dapat mengakses data shipping company, Dapat mengakses data agent company, Dapat mengakses data exportir, Dapat mengakses data consignee / notify, Dapat mengakses data consignee import, Dapat mengakses data shipper import, Dapat mengakses data airline, Dapat mengakses data sales, Dapat mengakses data petugas lapangan, Dapat mengakses data harga export, Dapat mengakses data tagihan, Dapat mengakses data harga import, Dapat mengakses data transaksi stuffing plan, Dapat mengakses data transaksi job order, Dapat mengakses data transaks permohonan pengambilan $\mathrm{B} / \mathrm{L}$, Dapat mengakses fungsi pencarian data pada database yang bisa diakses oleh Supervisor Hider.

- Hak akses Read-only terdiri dari: Dapat mengakses data harga export (read-only), Dapat mengakses data tagihan (read-only), Dapat mengakses data harga import. (readonly), Dapat mengakses fungsi pencarian data pada database yang bisa diakses oleh Read-only.

- Hak akses Marketing terdiri dari: Dapat mengakses data transaksi stuffing plan, Dapat mengakses data transaksi job order, Dapat mengakses data transaksi permohonan pengambilan B/L, Dapat mengakses data transaksi arrival notice.

- Hak akses Document Dept terdiri dari Dapat mengakses semua laporan.

- Hak akses Account Dept terdiri dari: Dapat mengakses data finansial invoice to shipper, Dapat mengakses data finansial credit note, Dapat mengakses data finansial finance process, Dapat mengakses data finansial refund voucher, Dapat mengakses data finansial bukti pengeluaran kas, Dapat mengakses data finansial discount voucher.

- Hak akses FCL dapat akses untuk Dapat mengakses data harga FCL (read-only), Dapat mengakses data transaksi FCL

- Hak akses LCL yaitu Dapat mengakses data harga LCL (read-only), dan Dapat mengakses data transaksi LCL

Tabel 1. UAT Menu Login User

\begin{tabular}{|c|c|c|c|c|c|c|}
\hline No & Test case & $\begin{array}{l}\text { Pre- } \\
\text { condition }\end{array}$ & Test steps & $\begin{array}{l}\text { Expected } \\
\text { Result }\end{array}$ & $\begin{array}{l}\text { Actual } \\
\text { Result }\end{array}$ & Status \\
\hline \multicolumn{7}{|c|}{ Modul Login } \\
\hline L-01 & $\begin{array}{l}\text { Login as } \\
\text { TOP } \\
\text { Supervisor }\end{array}$ & $\begin{array}{l}\text { Punya akun } \\
\text { TOP } \\
\text { Supervisor }\end{array}$ & $\begin{array}{l}\text { 1. Buka Aplikasi } \\
\text { 2. Masukkan } \\
\text { Username: 'Devi' } \\
\text { 3. Masukkan } \\
\text { Password: 'a' } \\
\text { 4. Klik Login } \\
\text { 5. Masukkan Tahun } \\
\text { Periode Saat ini }\end{array}$ & $\begin{array}{l}\text { 1. Masuk } \\
\text { sebagai TOP } \\
\text { Supervisor } 2 \text {. } \\
\text { Memiliki akses } \\
\text { ke semua sub } \\
\text { menu }\end{array}$ & $\begin{array}{l}\text { 1. Masuk } \\
\text { sebagai } \\
\text { TOP } \\
\text { Supervisor } \\
\text { 2. Memiliki } \\
\text { akses ke } \\
\text { semua sub } \\
\text { menu }\end{array}$ & ok \\
\hline L-02 & $\begin{array}{l}\text { Login as } \\
\text { Supervisor }\end{array}$ & $\begin{array}{l}\text { Punya akun } \\
\text { Supervisor }\end{array}$ & $\begin{array}{l}\text { 1. Buka Aplikasi } \\
\text { 2. Masukkan } \\
\text { Username: 'Ozmar' } \\
\text { 3. Masukkan } \\
\text { Password: 'a' } \\
\text { 4. Klik Login } \\
\text { 5. Masukkan Tahun } \\
\text { Periode Saat ini }\end{array}$ & $\begin{array}{l}\text { 1. Masuk } \\
\text { sebagai } \\
\text { Supervisor } \\
\text { 2. Memiliki } \\
\text { akses ke semua } \\
\text { sub menu } \\
\text { (Kecuali Menu } \\
\text { Data Pengguna) }\end{array}$ & $\begin{array}{l}\text { 1. Masuk } \\
\text { sebagai } \\
\text { Supervisor } \\
\text { 2. Memiliki } \\
\text { akses ke } \\
\text { semua sub } \\
\text { menu }\end{array}$ & ok \\
\hline L-03 & $\begin{array}{l}\text { Login as } \\
\text { Supervisor } \\
\text { Hider }\end{array}$ & $\begin{array}{l}\text { Punya akun } \\
\text { Supervisor } \\
\text { Hider }\end{array}$ & $\begin{array}{l}\text { 1. Buka Aplikasi } \\
\text { 2. Masukkan } \\
\text { Username: 'KEVIN' } \\
\text { 3. Masukkan } \\
\text { Password: 'a' } \\
\text { 4. Klik Login } \\
\text { 5. Masukkan Tahun } \\
\text { Periode Saat ini }\end{array}$ & $\begin{array}{l}\text { 1. Masuk } \\
\text { sebagai } \\
\text { Supervisor Hider } \\
\text { 2. Memiliki } \\
\text { akses ke semua } \\
\text { sub menu } \\
\text { (Kecuali Menu } \\
\text { Data Pengguna } \\
\text { dan Fungsi }\end{array}$ & $\begin{array}{l}\text { 1. Masuk } \\
\text { sebagai } \\
\text { Supervisor } \\
\text { Hider } \\
\text { 2. Memiliki } \\
\text { akses ke } \\
\text { semua sub } \\
\text { menu }\end{array}$ & ok \\
\hline
\end{tabular}

\subsection{System Security \& Support (fully operating systems)}

Pada Gambar 5 merupakan sebuah System Security \& Support Diagram di dalam Aplikasi Freight Forwading ketika sebuah transaksi pemesanan jasa berlangsung. Tahapan transaksi dari awal hingga selesai dijabarkan melalui list berikut:

1. Marketing menginput transaksi dari customer 
2. Supervisor Hider mengecek ketersediaan jasa yang diinginkan customer

3. Staff LCL atau FCL mengkonfirmasi ketersediaan muatan container

4. Staff Air Freight atau Freight mengkonfirmasi ketersediaan jadwal pengantaran barang.

5. Supervisor Hider mengkonfirmasi transaksi

6. Marketing menerima bayaran dari customer

7. Supervisor Hider mengkonfirmasi bayaran melalui sistem
8. Supervisor Hider memproses transaksi

9. Account Dept merekam dan mencatat transaksi dan menyimpan laporan

10. Document Dept mencetak laporan untuk diberikan kepada Supervisor

11. Supervisor menerima laporan

12. TOP Supervisor mengawasi seluruh aktifitas bisnis melalui sistem

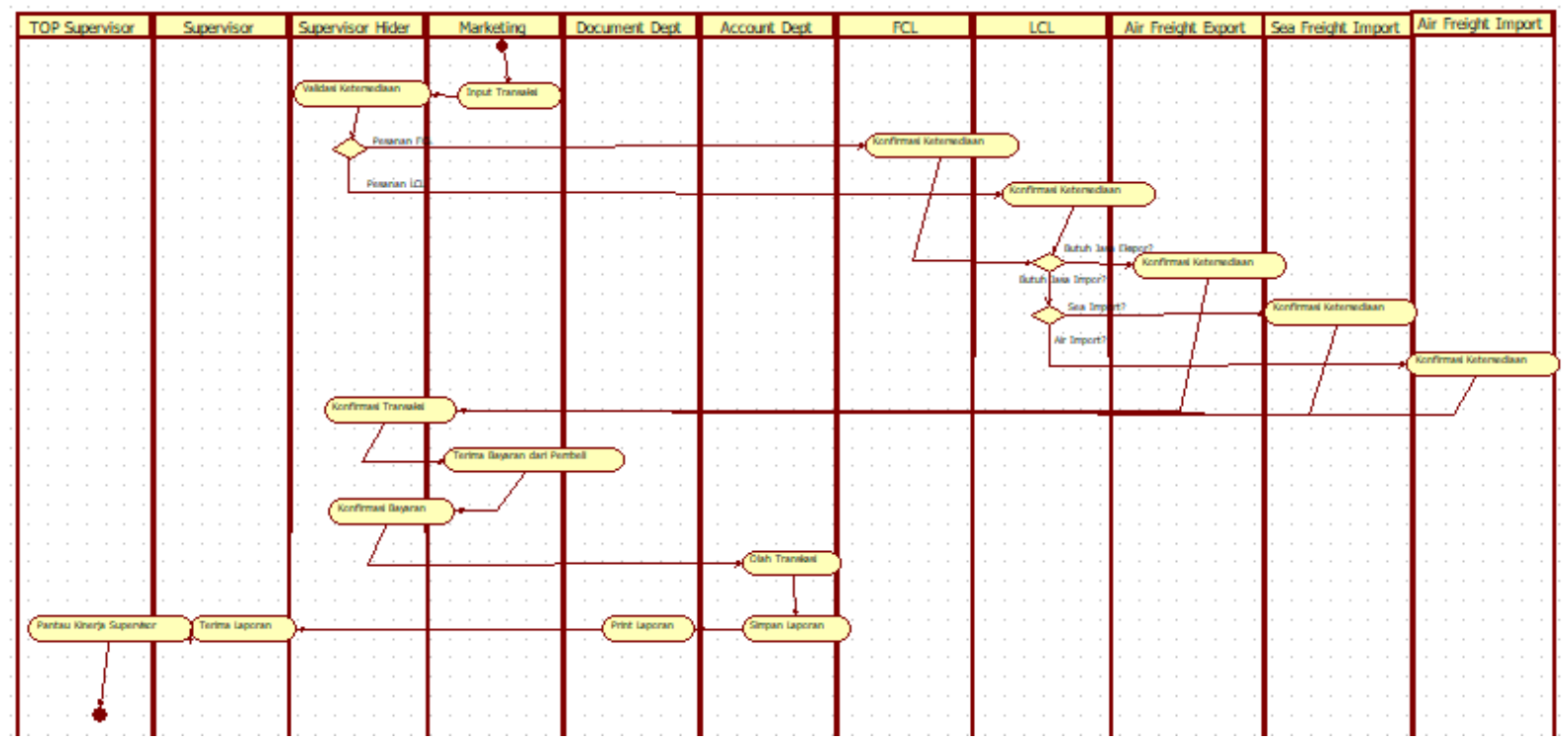

Gambar 5. System Security \& Support Diagram

Pada Tabel 1. UAT Menu Login User, karena keterbatasan halaman dari paper ini, maka hanya disampaikan test case ke user TOP Supervisor, Supervisor dan Hider Supervisor, terdiri dari No yaitu nomor urut untuk menguji dari scenario yang dilakukan, sedangkan test case adalah apa yang diinginkan oleh user pada tampilan aplikasi, precondition memperlihatkan kondisi apa yang diharapkan sebelum menampilkan menu yang diharapkan, test steps adalah langkah yang dilakukan oleh user untuk masuk ke software, expected results adalah hasil yang di harapkan oleh user berdasarkan permintaan dari aplikasi, sedangkan actual result adalah kenyataan yang ada pada saat aplikasi di tampilkan, dan status menunjukan apakah aplikasi berjalan sesuai yang diharapkan.

\section{Kesimpulan}

Pengembangan Software Freight Forwarding Angkutan Darat untuk Antar Propinsi Menggunakan SDLC Water Fall oleh peneliti menjelaskan bahwa metode ini lebih terstruktur dan mudah untuk diterapkan pada team yan kecil, dalam rancang bangun system ini ada beberapa proses membutuhkan waktu lebih lama dalam penelitian ini. Dalam proses System Planning (Preliminary Investigation
Report) untuk memenuhi kebutuhan dari pengguna dari perusahaan jasa angkutan truk antar propinsi, tahapan-tahapan pada SDLC ini lebih terperinci dengan pembagian proses menjadi 5 tahapan yaitu Planning, analysis, design dan Implementasi serta security \& support. Dengan tahapan tersebut hasil pengembangan yang dihasilkan menjadi lebih baik dan lengkap.

Berdasarkan hasil implementasi di lapangan yaitu telah dapat meningkatkan proses bisnis dan pendapatannya secara signifikan serta kinerja operationalnya meningkat dengan lebih baik, bisa dilihat dari hasil laporan yang baik ke internal perusahaan berupa laporan yang diinginkan dengan mudah dapat di peroleh.

\section{Ucapan Terima Kasih}

Penelitian tentang Rancang Bangun Software Freight Forwarding Angkutan Darat untuk Pengiriman Barang Antar Propinsi Menggunakan SDLC Water Fall ini terlaksana berkat hibah dana penelitian dosen pemula (PDP) di tahun akademik 2020/2021 dari Direktorat Jenderal Pendidikan Tinggi, Kementerian Pendidikan dan Kebudayaan. 


\section{Referensi}

Amron, M. T., Hassan, S. B. A., Hudin, M. S. S., \& Janom, N. (2018). Inventory Control System Using Waterfall Development Model. International Journal of Engineering \& Technology, 7(4.42), 138141. www.sciencepubco.com/index.php/lJET

Andry, J. F., Agung, H., \& Erlyana, Y. (2016). Management Information System for Order Fulfillment: A Case Study. Proceeding of 9th International Seminar on Industrial Engineering and Management, 1-8.

Andry, J. F., \& Honni. (2017). Using Backup and Restore Automation from Disaster in University Information Systems. 2nd International Conference on Innovative Research Across Disciplines (ICIRAD 2017), 134, 1-5. https://doi.org/10.2991/icirad-17.2017.1

Andry, J. F., Suroso, J. S., \& Bernanda, D. Y. (2018). Improving Quality Of Smes Information System Solution With ISO 9126. Journal of Theoretical and Applied Information Technology, 96(14), 46104620.

Bassil, Y. (2012). A Simulation Model for the Spiral Software Development Life Cycle. International Journal of Innovative Research in Computer and Communication Engineering (IJET), 2(5), 3823-3830.

https://doi.org/10.15680/ijircce.2015.0305 013

Egwoh, A. Y., \& Nonyelum, O. F. (2017). A Software System Development Life Cycle Model for Improved Students Communication and Collaboration. International Journal of Computer Science \& Engineering Survey, 8(4), 1-10. https://doi.org/10.5121/ijcses.2017.8401

Geasela, Y. M., Ranting, P.-, \& Andry, J. F. (2018). Analisis User Interface terhadap Website Berbasis E-Learning dengan Metode Heuristic Evaluation. Jurnal Informatika, 5(2), 270-277. https://doi.org/10.31311/ji.v5i2.3741

Gharajeh, M. S. (2019). Waterative Model: An Integration of the Waterfall and Iterative Software Development Paradigms. Database Systems Journal, X, 75-81.

Gunawan, F. E., Andry, J. F., Wijaya, A. S., \& Tannady, H. (2021). Implementation Android Based E-Commerce for Improving Business Process and Increasing Revenue. Turkish Journal of Computer and Mathematics Education (TURCOMAT), 12(3), 4418-4427. https://doi.org/10.17762/turcomat.v12i3.18 21

Madyatmadja, E. D., Liliana, L., Chakir, A., \& Andry, J. F. (2021). Implementation of The Zachman Framework Using Capsicum Model For Electrical Equipment Trading Industry. ICIC Express Letters, Part B: Applications, 12(3), 207-213. https://doi.org/10.24507/icicelb.12.03.207

Majalah Pajak. (2021). Saat Aplikasi Mengganti "Freight Forwarder." Https://Majalahpajak.Net/Saat-AplikasiMengganti-Freight-Forwarder/ di akses tlg 03 Maret 2021.

Nurlifa, A., Kusumadewi, S., \& Kariyam. (2014). Analisis Pengaruh User Interface Terhadap Kemudahan Penggunaan Sistem Pendukung Keputusan Seorang Dokter. Prosiding SNATIF Ke-1 Tahun 2014, 333-340.

SmartLogistik. (2020). Kemenhub Fokus Jaga Kelancaran Angkutan Logistik di Tengah Pandemi.

Https://Smartlogistics.Id/Kemenhub-

Fokus-Jaga-Kelancaran-Angkutan-

Logistik-Di-Tengah-Pandemi/ di akses tlg 03 Mei 2021.

Sudarsono, B. G., Fransiscus, Hartono, H., Bernanda, D. Y., \& Andry, J. F. (2020). Adopting Scrum Framework In A Software Development Of Payroll Information System. International Journal of Advanced Trends in Computer Science and Engineering, 9(3), 2604-2611. https://doi.org/10.30534/ijatcse/2020/1793 2020

Suryantara, I. G. N., \& Andry, J. F. (2018). Development of Medical Record With Extreme Programming SDLC. International Journal of New Media Technology (IJNMT), 5(1), 47-53. https://doi.org/10.31937/ijnmt.v5i1.706

Tilley, S., \& Rosenblatt, H. (2017). Systems Analysis and Design. In Shelly Cashman Series, Cengage Learning. 